\title{
EFFICIENCY OF WATER QUALITY INDEX APPROACH AS AN EVALUATION TOOL
}

\author{
EFEKTYWNOŚĆ OCENY JAKOŚCI WODY \\ ZA POMOCĄ INDEKSU JAKOŚCI
}

\begin{abstract}
This study aimed to demonstrate efficiency of documented index method "universal water quality index-UWQI" to evaluate surface water quality and investigate seasonal and temporal changes, in the case of Gediz River Basin Turkey. UWQI expressed results relative to levels according to criteria specified in European legislation (75-440 EEC). The method produced a unitless number ranging from 1 to 100 and a higher number was indicator of better water quality. Water quality is classified into five classes and index scores between 95-100 represent excellent and lower than 24 represent poor quality. In the study, dissolved oxygen- $\mathrm{DO}, \mathrm{pH}, \mathrm{mercury}-\mathrm{Hg}$, cadmium-Cd, total phosphorus-TP, biochemical oxygen demand- BOD and nitrate nitrogen- $\mathrm{NO}_{3}-\mathrm{N}$ have been chosen as index determinants. Samples analyzed for these variables were collected from five stations on monthly basis along two years. Based on UWQI classification scheme, water quality at sampling stations had scores below 40 and assigned to "marginal" which is between fair and poor quality class. On the other hand sub-indices of water quality determinants showed seasonal differences for some parameters. Cd concentrations were higher in "high flow" and lower values were observed in "low flow" periods. This was explained by negative impact of urban runoff on water quality. On the other hand DO concentrations were higher in "high flow" period. Under "low flow" conditions water quality at upstream stations (where the industrial density is low) was comparably better than downstream part. The study showed that index approach can be efficient tool to: a) evaluate water quality, b) investigate spatial and seasonal variations and finally, c) extract required information from complex data sets that is understandable by non-technical people.
\end{abstract}

Keywords: Universal Water Quality Index, 75-440 EEC, sub-index function, index score, water pollution

\section{Introduction}

Water quality assessment provides to understand whether water quality conditions are getting better or worse over time; and how natural features and human activities affect those conditions. Water quality is defined in terms of its physical, chemical and biological parameters. Traditional assessment methods are based on the comparison of experimentally determined parameter values with the existing guidelines but in many cases it does not readily give a information on status of the source. Water quality index (WQI) method aims

\footnotetext{
${ }^{1}$ Department of Environmental Engineering, Faculty of Engineering, Dokuz Eylul University, Tinaztepe Campus Buca, 35160 Izmir, Turkey, phone +90(232)3017135, fax +90(232)4531143

${ }^{2}$ Faculty of Fisheries, Ege University, Bornova, 35100 Izmir, Turkey, email: vildangundogdu@ yahoo.com

*Corresponding author: hulya.boyacioglu@deu.edu.tr
} 
to give an index score to the water quality of a source by translating the list of constituents and their concentrations present in a sample into a single value. In other words the indices are composite representations of a condition or situation derived from a combination, done in certain ways, of several relevant but noncommensurate observed measurements. The index number could be understandable, useful to technical and policy individuals as well as the general public who are interested in the water quality results and not expected to understand "raw" environmental data or some technical calculations etc. This is particularly important in reporting the state of the environment [1-7].

The use of a WQI was initially proposed by Horton in 1965 [8] and since then, a great deal of consideration has been given to the development of methods. The main objective was to provide a tool for simplifying the reporting of water quality data in various countries ie United States, Canada, Malaysia etc. These indices assess the appropriateness of water quality for a variety of uses. As the approaches and policy objectives differ for different countries they were developed as a specific tool for each authority [9-16].

In the study applicability of Universal Water Quality Index (WQI) developed by Boyacioglu [16] by referencing European standard has been demonstrated in the case of Gediz River Basin. The objective was to: a) find out the relative relationship between the reference standards and water quality $b$ ) investigate seasonal and spatial differences in terms of quality and c) extract required information from complex data sets that is understandable by non-technical people.

\section{Study area}

Gediz Basin is located in the west of Turkey. Gediz River flows from east to west into the Aegean See just north of Izmir. The river is about $401 \mathrm{~km}$ long and drains an area of $17500 \mathrm{sq} \mathrm{km}$ as shown in Figure 1 [17].

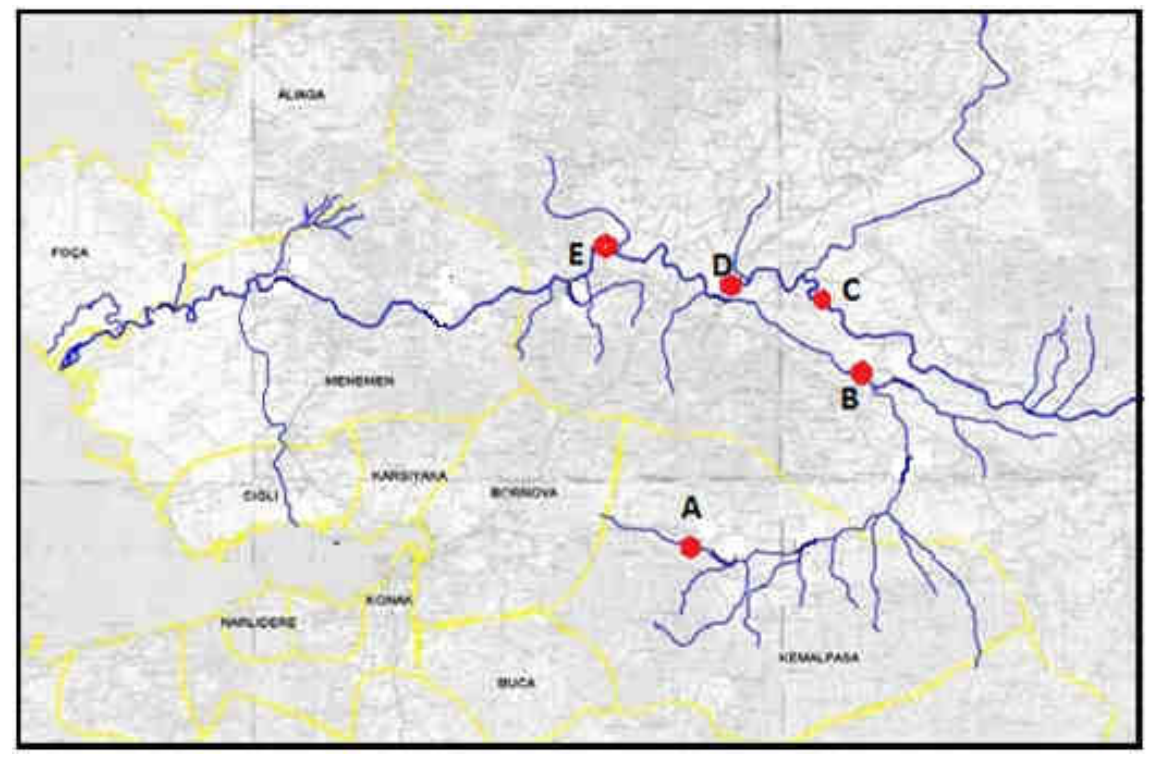

Fig. 1. Gediz River and water quality monitoring stations 
The major problems regarding water quality in the region are eutrophication and oxygen depletion due to point (industrial and domestic) and diffuse sources (drainage from agricultural \& forest areas, and uncontrolled discharges) [18]. Inspite of quality problems observed in some parts, this study results will be used to test whether the water can be used for human consumption or not in the studied area especially in the upstream part where industrial density is relatively low.

\section{Study method}

Universal Water Quality Index-UWQI was designed to reflect appropriateness of quality of surface water source used for drinking water supply. The development of UWQI was started with the selection of variables that influence surface water quality. Twelve water quality parameters including cadmium, cyanide, mercury, selenium, arsenic, fluoride, nitrate-nitrogen, dissolved oxygen, biochemical oxygen demand, phosphorus, $\mathrm{pH}$ and total coliform were considered as the significant indicator parameters of UWQI to assess surface water sources [16]. Sub-index values were determined using mathematical expressions, which were given at Table 1 to assign each parameter a value between 0 and 100. Sub-index functions were determined based on "the quality required of surface water intended for the abstraction of drinking water in the Member States-75/440/EEC" [19] set by the Council of the European Communities and "Turkish Water Pollution Control Regulation" [20].

Table 1

Mathematical equations formulated for UWQI [16]

\begin{tabular}{|c|c|c|}
\hline Variable & Range & Sub-index function \\
\hline BOD & $\begin{array}{c}X<3 \\
3 \leq X<5 \\
5 \leq X<7 \\
X \geq 7\end{array}$ & $\begin{array}{c}y=100 \\
y=-25 X+175 \\
y=-22.5 X+162.5 \\
y=0\end{array}$ \\
\hline Nitrate-nitrogen & $\begin{array}{c}X \leq 5 \\
5<X \leq 10 \\
10<X \leq 20 \\
X>20\end{array}$ & $\begin{array}{c}y=100 \\
y=-10 X+150 \\
y=-4.5 x+95 \\
y=0\end{array}$ \\
\hline Arsenic & $\begin{array}{c}X \leq 0.02 \\
0.02<X \leq 0.05 \\
0.05<X \leq 0.1 \\
X>0.1\end{array}$ & $\begin{array}{c}y=100 \\
y=-1666.7 X+133.33 \\
y=-900 X+95 \\
y=0\end{array}$ \\
\hline Dissolved oxygen & $\begin{array}{c}X \geq 8 \\
8<X \leq 6 \\
6<X \leq 3 \\
X<3\end{array}$ & $\begin{array}{c}y=100 \\
y=25 X-100 \\
y=15 X-40 \\
y=0\end{array}$ \\
\hline Fluoride & $\begin{array}{c}X \leq 1 \\
1<X \leq 2 \\
X>2\end{array}$ & $\begin{array}{c}y=100 \\
y=-95 X+194.17 \\
y=0\end{array}$ \\
\hline Total phosphorus & $\begin{array}{c}X \leq 0.02 \\
0.02<X \leq 0.16 \\
0.16<X \leq 0.65 \\
X>0,65\end{array}$ & $\begin{array}{c}y=100 \\
y=-357.14 X+107.14 \\
y=-91.837 X+64.694 \\
y=0\end{array}$ \\
\hline Mercury & $\begin{array}{c}X \leq 0.0001 \\
0.0001<X \leq 0.0005 \\
0.0005<X \leq 0.002 \\
X>0.002\end{array}$ & $\begin{array}{c}y=100 \\
y=-125000 X+112.5 \\
y=-30000 X+65 \\
y=0\end{array}$ \\
\hline
\end{tabular}




\begin{tabular}{|c|c|c|}
\hline Variable & Range & Sub-index function \\
\hline Selenium & $\begin{array}{c}X \leq 0.01 \\
0.01<X \leq 0.02 \\
X>0.02\end{array}$ & $\begin{array}{c}y=100 \\
y=-4500 X+95 \\
y=0\end{array}$ \\
\hline Cyanide & $\begin{array}{c}\mathrm{X} \leq 0.01 \\
0.01<\mathrm{X} \leq 0.05 \\
0.05<\mathrm{X} \leq 0.1 \\
\mathrm{X}>0.1\end{array}$ & $\begin{array}{c}y=100 \\
y=-1250 x+112.5 \\
y=-900 x+95 \\
y=0\end{array}$ \\
\hline Cadmium & $\begin{aligned} X & \leq 0.003 \\
0.003 & <X \leq 0.005 \\
0.005 & <X \leq 0.010 \\
X & >0.010\end{aligned}$ & $\begin{array}{c}y=100 \\
y=-25000 x+175 \\
y=-9000 x+95 \\
y=0\end{array}$ \\
\hline Total Coliform & $\begin{array}{c}X \leq 50 \\
50<X \leq 5000 \\
5000<X \leq 50000 \\
X>50000\end{array}$ & $\begin{array}{c}y=100 \\
y=-10.857 \ln X+142.47 \\
y=-21,715 \ln X+284.95 \\
y=0\end{array}$ \\
\hline $\mathrm{pH}$ & $\begin{aligned} 6.5 \leq X \leq 8.5 \\
5.5 \leq X \leq 6.4 \text { and } 8.6 \leq X \leq 9 \\
X<5.5 \text { and } X>9\end{aligned}$ & $\begin{array}{c}\mathrm{y}=100 \\
\mathrm{y}=50 \\
\mathrm{y}=0\end{array}$ \\
\hline
\end{tabular}

According to EC legislation (75/440/EEC), water quality of surface waters intended for the abstraction of drinking water is classified into three groups. For each class the treatment level required to transform surface water into drinking water is different. Turkish WPCR also has quite a similar categorisation scheme, the main difference being that a Category IV is added to the Turkish standard water quality parameters, in which the values exceed those set for Category III.

Rates assigned to each of these variables considering health and ecological effects were presented in Table 2 .

Table 2

Rates assigned to variables of concern [16]

\begin{tabular}{|c|c|c|c|}
\hline Category & Variable & Basis for Inclusion & Rating \\
\hline \multirow{8}{*}{ Health hazard } & Total Coliform & Indicator of fecal contamination & 4 \\
\hline & Cadmium & \multirow{3}{*}{$\begin{array}{c}\text { Chemicals from industrial and domestic } \\
\text { discharges }\end{array}$} & 3 \\
\hline & Cyanide & & 3 \\
\hline & Mercury & & 3 \\
\hline & Selenium & \multirow{3}{*}{ Naturally occurring chemicals } & 3 \\
\hline & Arsenic & & 4 \\
\hline & Fluoride & & 3 \\
\hline & Nitrate-nitrogen & Chemical from agricultural activities & 3 \\
\hline \multirow{2}{*}{ Aesthetic } & DO & \multirow{2}{*}{ Operational monitoring parameters } & 4 \\
\hline & $\mathrm{pH}$ & & 1 \\
\hline \multirow[b]{2}{*}{ Oxygen depletion } & BOD & Indicator of organic pollution & 2 \\
\hline & Total phosphorus & $\begin{array}{l}\text { It is included to satisfy the ecological } \\
\text { requirements of certain types of environment }\end{array}$ & 2 \\
\hline
\end{tabular}

Weighted sum method was employed to get overall index value using weights:

$$
U W Q I=\sum_{i=1}^{n} W_{i} I_{i}
$$

where: $W_{i}$ - weight factor for $i^{\text {th }}$ parameter, $I_{i}$ - sub-index for $i^{\text {th }}$ parameter. 
Weight factor for a parameter was determined by dividing rate of this parameter into sum of rates of index determinants used for the index calculation [16].

The proposed UWQI index categorization schema was given in Table 3.

UWQI index categorization schema [16]

Table 3

\begin{tabular}{|c|c|}
\hline Rank & WQI value \\
\hline Excellent & $95-100$ \\
\hline Good & $75-94$ \\
\hline Fair & $50-74$ \\
\hline Marginal & $25-49$ \\
\hline Poor & $0-24$ \\
\hline
\end{tabular}

In the study efficiency of the method was demonstrated in the case of Gediz River Basin Turkey. In this scope samples taken from five stations on monthly basis along two years and analyzed for $\mathrm{DO}, \mathrm{pH}, \mathrm{Hg}, \mathrm{Cd}, \mathrm{TP}, \mathrm{BOD}$ and $\mathrm{NO}_{3}-\mathrm{N}$ variables were chosen as index determinants. Suitability of the quality was examined and spatial seasonal variations in quality was also investigated.

\section{Results and discussion}

\section{Spatial variations in water quality}

UWQI method was used to investigate spatial variations in the region by examining index values at monitoring sites. In this scope the sub-index values were assigned to variables based on median values of each data set comprising all the sampling period. Overall index values were determined using mathematical equations and parameter weights were presented in Tables 1 and 2. Weighted sum method was used for the calculations.

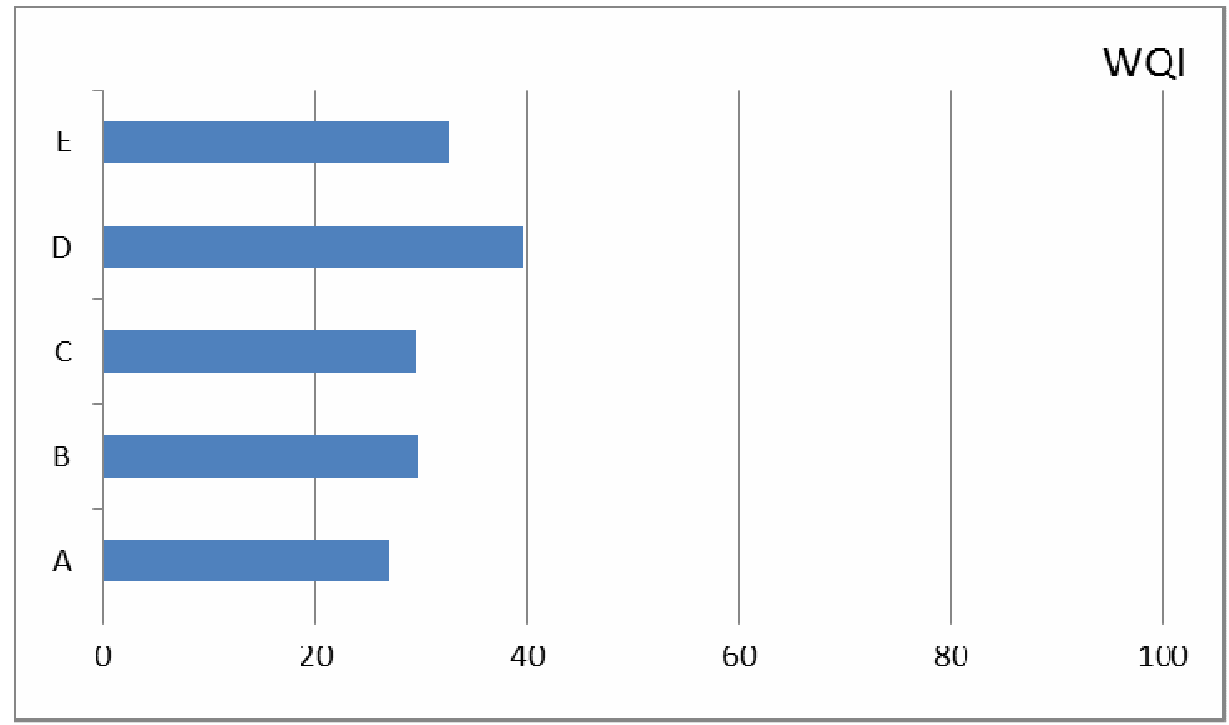

Fig. 2. Spatial differences of UWQI values 
Water quality sub-index values and overall index scores

\begin{tabular}{|c|c|c|c|c|c|c|c|c|}
\hline Stations & \multicolumn{9}{|c|}{ Water Quality Variables } \\
\hline & DO & $\mathbf{p H}$ & $\mathbf{H g}$ & $\mathbf{C d}$ & $\mathbf{T P}$ & $\mathbf{B O D}$ & NO $_{\mathbf{3}}$-N & WQI \\
\hline A & 15 & 100 & 0 & 10 & 0 & 0 & 100 & $\mathbf{2 7}$ \\
\hline B & 24 & 100 & 0 & 14 & 0 & 0 & 100 & $\mathbf{3 0}$ \\
\hline C & 29 & 100 & 0 & 5 & 0 & 0 & 100 & $\mathbf{3 0}$ \\
\hline D & 54 & 100 & 0 & 32 & 0 & 0 & 100 & $\mathbf{4 0}$ \\
\hline E & 16 & 100 & 0 & 41 & 0 & 0 & 100 & $\mathbf{3 3}$ \\
\hline $\begin{array}{c}\text { weight } \\
\text { factor }\end{array}$ & 0.222 & 0.056 & 0.167 & 0.167 & 0.111 & 0.111 & 0.167 & \\
\hline
\end{tabular}

Results presented in Table 4 showed that Station D had better quality compared with the other sites. On the other hand, despite of spatial differences, water quality index scores were lower than "40" in all locations (see Fig. 2). In other words water quality was marginal as described by UWQI categorization scheme. Moreover, $\mathrm{Hg}, \mathrm{Cd}, \mathrm{TP}$ and BOD were the parameters having risk with high concentrations (low index scores).

\section{Seasonal variations in water quality}

In the study to investigate seasonal variations in water quality, data sets were divided into two flow periods as "high flow" and "low flow". Median values of discharges observed along the study period (see Table 5) were the basis for this classification. Discharges lower than median values were assigned to "low flow" and higher values to "high flow period".

Median values of discharges at monitoring stations

Table 5

\begin{tabular}{|c|c|}
\hline Station & $\mathbf{Q}\left[\mathbf{m}^{\mathbf{3}} / \mathbf{s}\right]$ \\
\hline A & 0.238 \\
\hline B & 0.807 \\
\hline C & 1.836 \\
\hline D & 4.098 \\
\hline E & 5.085 \\
\hline
\end{tabular}

Sub-index scores in low flow period

Table 6

\begin{tabular}{|c|c|c|c|c|c|c|c|}
\hline Stations & \multicolumn{7}{|c|}{ Water Quality Variables } \\
\hline & DO & $\mathbf{p H}$ & $\mathbf{H g}$ & $\mathbf{C d}$ & $\mathbf{T P}$ & $\mathbf{B O D}$ & $\mathbf{N O}_{\mathbf{3}}-\mathbf{N}$ \\
\hline $\mathrm{A}$ & 0 & 100 & 0 & 100 & 0 & 0 & 100 \\
\hline B & 0 & 100 & 0 & 100 & 0 & 0 & 100 \\
\hline C & 27 & 100 & 0 & 100 & 0 & 0 & 100 \\
\hline D & 38 & 100 & 0 & 100 & 0 & 0 & 100 \\
\hline E & 0 & 100 & 0 & 100 & 0 & 0 & 100 \\
\hline
\end{tabular}

Index values calculated for each station for two flow periods indicated that under "low flow" conditions water quality at upstream stations was comparably better than downstream part (see Fig. 3). Moreover sub-index values assigned to each variable presented in Tables 6 and 7 showed that $\mathrm{Cd}$ and DO created seasonal differences. In contrast to high DO scores, $\mathrm{Cd}$ has lower index values in "high flow" period. Low scores (in other words high $\mathrm{Cd}$ concentrations) in high flow period were explained by effect of discharges from diffuse 
sources on surface water quality. This finding was in parallel to the research which reported that a large proportion of the cadmium load in the aquatic environment was due to diffuse pollution originating from many different sources rather than from point sources [21].

Table 7

Sub-index scores in high flow period

\begin{tabular}{|c|c|c|c|c|c|c|c|}
\hline Stations & \multicolumn{7}{|c|}{ Water Quality Variables } \\
\hline & DO & pH & Hg & Cd & TP & BOD & NO3-N \\
\hline A & 50 & 100 & 0 & 5 & 0 & 0 & 100 \\
\hline B & 75 & 100 & 0 & 0 & 0 & 0 & 100 \\
\hline C & 29 & 100 & 0 & 5 & 0 & 0 & 100 \\
\hline D & 73 & 100 & 0 & 0 & 0 & 0 & 100 \\
\hline E & 75 & 100 & 0 & 5 & 28 & 0 & 100 \\
\hline
\end{tabular}

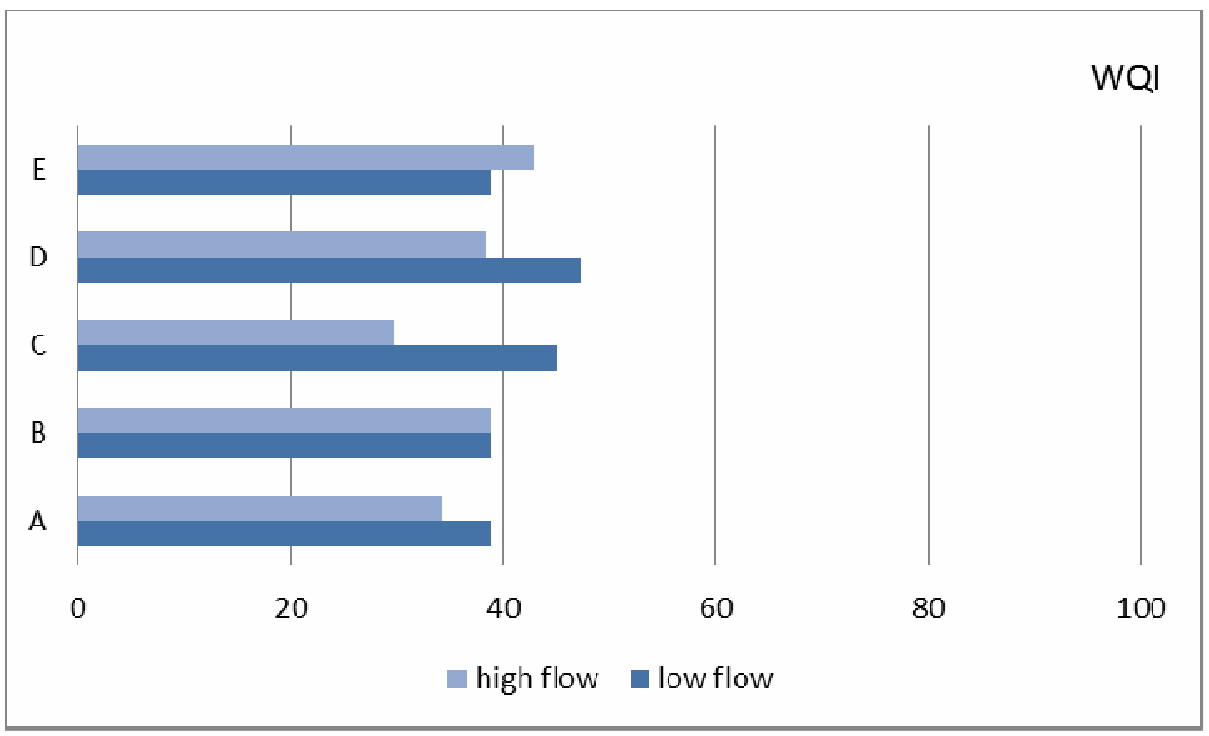

Fig. 3. Seasonal changes of UWQI values

On the other hand low sub-index values for TP, BOD and $\mathrm{Hg}$ in both seasons were indicator of discharges from residential areas and industrial facilities.

\section{Conclusions}

Public and non-technical people need to know whether quality of waterbody is adequate/sufficient to support designated uses. Water quality index approach can meet this expectation by converting complex data sets into unitless index scores and assign these values to category formed based on the referenced criteria. In the study, surface water quality was evaluated and seasonal and temporal changes were investigated, in the case of Gediz River Basin Turkey using documented method "Universal Water Quality Index". Samples taken from five stations and analyzed for $\mathrm{DO} \mathrm{pH}, \mathrm{Hg}, \mathrm{Cd}, \mathrm{TP}, \mathrm{BOD}$ and $\mathrm{NO}_{3}-\mathrm{N}$ variables were chosen as index determinants. Results showed that water quality was 
marginal in the basin. Under low flow conditions water quality at upstream stations (where the industrial density is low) was comparably better than downstream part. DO and Cd were the variables creating difference between two seasons. High Cd concentrations in "high flow" period were explained by impact of urban run-off. On the other hand, low index values for $\mathrm{TP}, \mathrm{BOD}$ and $\mathrm{Hg}$ through year was indicator of influence from industrial and domestic discharges. This study showed that index method is a useful tool to extract information on relative relationship between the reference standards and water quality conditions. Moreover spatial and temporal changes can also be investigated by translating complex data set into information that is understandable by non-technical people.

\section{References}

[1] Nagels JW, Colley D, Smith DG. A water quality index for contact recreation in New Zealand. Water Sci Technol. 2001;43(5):285-292.

[2] Sargaonkar A, Deshpande V. Development of an overall index of pollution for surfacewater based on a general classification scheme in Indian context. Environ Monit Assess. 2003;89(1):43-67. DOI: 10.1023/A:1025886025137.

[3] Abbasi T, Abbasi SA. Water Quality Indices. Elsevier B.V.; 2012.

[4] Kumar A, Dua A. Water quality index for assessment of water quality of river Ravi at Madhopur (India). Global J Environ Sci. 2009;8(1):49-57.

[5] Hurley T, Sadiq R, Mazumder A. Adaptation and evaluation of the Canadian Council of Ministers of the Environment Water Quality Index (CCME WQI) for use as an effective tool to characterize drinking source water quality. Water Res. 2012;46(11):3544-3552. DOI: 10.1016/j.watres.2012.03.061.

[6] Kahler-Royer CA. A water quality index devised for the Des Moines River in Central IOWA. IOWA State University. Master of Science thesis - Supervised by. Prof. T. Al Austin, 1999.

[7] Prasad RDS, Sadashivaiah C, Ranganna G. Water quality index and regression models for predicting water quality and water quality parameters for Tumkur Amanikere Lake Watershed, Tumkur, Karnataka, India. Green pages, 2009; Accessed on 1 February 2013 from http://www.eco-web.com/edi/index.htm.

[8] Horton RK. An index-number system for rating water quality. J Water Pollut Control Federat. 1965;37(3):300-306.

[9] Ramesh S, Sukumaran N, Murugesan AG, Rajan MP. An innovative approach of Drinking Water Quality Index - A case study from Southern Tamil Nadu, India. Ecol Indicat. 2010;10(4):857-868. DOI:10.1016/j.ecolind.2010.01.007.

[10] Królak E, Strzałek M, Korycińska M. The usefulness of various indices in the assessment of water quality of a lowland river. Ecohydrol \& Hydrobiol. 2009;9(2-4):271-280. DOI: 10.2478/v10104-010-0007.

[11] Liou SM, Lien S, Wang SH. Generalized water quality index for Taiwan. Environ Monit Assess. 2004;96:35-52. DOI: 10.1023/B:EMAS.0000031715.83752.a1.

[12] Cude C. Oregon Water Quality Index: a tool for evaluating water quality management effectiveness. J Amer Water Resour Associat. 2001;37(1):125-137. DOI: 10.1111/j.1752-1688.2001.tb05480.x.

[13] El-Gafy I, Farid MN, El-Bahrawy A, Khalifa A, El-Basiony E, Abdelmotaleb M. Decision support system for evaluating the groundwater quality. Emirates J Eng Res. 2005;10(1):69-78.

[14] Debels P, Figueroa R, Urrutia R, Barra R, Niell X. Evaluation of water quality in the Chillan River (Central Chile) using physicochemical parameters and a modified water quality index. Environ Monit Assess. 2005;110(1-3):301-322. DOI: 10.1007/s10661-005-8064-1.

[15] Fulazzaky MA. Water quality evaluation system to assess the Brantas River water. Water Resour Manage. 2009;23(14):3019-3033. DOI: 10.1007/s11269-009-9421-6.

[16] Boyacioglu H. Development of a water quality index based on a European classification scheme. Water SA. 2007;33(1):101-106.

[17] MoEF. Republic of Turkey Ministry of Environment and Forestry. Gediz Basin Protection Action Plan. 2008.

[18] Minareci O, Öztürk M, Egemen O, Minareci E. Detergent and phosphate pollution in Gediz River, Turkey. Afr J Biotechnol. 2009;8(15):3568-3575.

[19] European Council-EC. Consolidated text produced by the CONSLEG system of the office for official publications of the European Communities. Council Directive of 16 June 1975 concerning the quality 
required of surface water intended for the abstraction of drinking water in the Member States (75/440/EEC). Office for Official Publications of the European Communities. CONSLEG: 1975L0440 31/12/1991.

[20] Official gazette (2004) Turkish Water Pollution Control Regulation. Numbered 25687 Dated 31.12.2004, Ankara. Revised in 2008 and 2010.

[21] ATSDR. U.S. Department of Health and Human Services Public Health Service Agency for Toxic Substances and Disease Registry. Draft toxicological profile for cadmium, Atlanta, Georgia: 2012.

\title{
EFEKTYWNOŚĆ OCENY JAKOŚCI WODY ZA POMOCĄ INDEKSU JAKOŚCI
}

\begin{abstract}
Abstrakt: Celem pracy było wykazanie skuteczności zastosowania uniwersalnego indeksu jakość wody UWQI w ocenie jakości wód powierzchniowych i badaniu ich zmian czasowych na przykładzie basenu rzeki Gediz w Turcji. UWQI wyraża wyniki zgodnie z kryteriami określonymi w prawodawstwie europejskim (75-440 EWG). Indeks przedstawiony jest za pomocą liczb niemianowanych, z zakresu od 1 do 100 . Im indeks jest większy, tym lepsza jest jakość wód. Jakość wody dzieli się na pięć klas, a wartość indeksu z zakresu 95-100 wskazuje na wody o najwyższej jakości. Wartości niższe od 24 oznaczają słabą jakość wód. Na wyznaczniki indeksu wybrano następujące parametry: tlen rozpuszczony (DO), pH, stężenia rtęci, kadmu, fosforu i azotu azotanowego oraz biochemiczne zapotrzebowanie na tlen. Próbki, w których badano te parametry, były pobierane z pięciu stacji raz w miesiącu, przez okres dwóch lat. Na podstawie schematu klasyfikacji UWQI próbkom przypisano indeksy poniżej 40, co pozwala na ocenę jakości wód jako przeciętną i niską. Z drugiej strony, dla niektórych parametrów współczynnik jakości wody wykazywał różnice sezonowe. Stężenia Cd były większe w czasie "silnych przepływów", natomiast mniejsze wartości obserwowano w okresie "słabych przepływów". Wytłumaczono to wpływem spływu miejskiego na jakość wody. Z drugiej strony stężenie DO było większe w okresie "silnych przepływów". W okresach "silnych przepływów" jakość wody w górze rzeki (gdzie gęstość przemysłu jest mała) była lepsza niż w jej dolnym biegu. Badanie wykazało, że zastosowanie indeksu może być skutecznym narzędziem do: a) oceny jakości wody, b) badania zmian przestrzennych i sezonowych oraz c) wyodrębniania takich informacji ze złożonych zbiorów danych, które są zrozumiałe dla niespecjalistów.
\end{abstract}

Słowa kluczowe: Uniwersalny Wskaźnik Jakości Wody, 75-440 EWG, funkcja sub-index, wynik indeksu, zanieczyszczenia wody 